\title{
Right Brain: Flip to the other side
}

Deepali Garg, MD, PDF, and Krishna Chaitanya Joshi, MD

Correspondence

Dr. Garg

deepa_garg10@yahoo.co.in

As I lie in bed and look at the white ceiling, My body is still and I have a sinking feeling.

Strangers in white gather around my bed, Bearers of hope or demons in my head.

I open my mouth and no words come out, I feel the earth shake; they say it's a seizure bout!

The nurse pushes a warm liquid in my vein,

Now I can't feel anything except the constant pain.

I have an aneurysm, on the basilar, they say.

I feel it's all over, is this my D-Day?

A blood vessel in my brain is all swollen and twisted, Ready to spew its venom and get my brain infested.

My arms and legs feel like a stone,

I am now a prisoner in my own body, all alone.

It gets harder with every breath that I take,

The light is fading, but I fight to keep awake.

Next thing I know, the surgeon puts a hole in my crown, My head feels lighter; a red liquid splashes on his gown.

With pressure out of my head, I gather my thoughts, Who am I? And how did I become so distraught?

Just yesterday, I was on the other end of the bed, Making decisions about someone else's head.

Life's ironies often get you by surprise,

You never know when you flip to the other side.

From the Departments of Neuroanesthesia (D.G.) and Neurosurgery (K.C.J.), Cleveland Clinic, OH. 


\title{
Neurology
}

\author{
Right Brain: Flip to the other side \\ Deepali Garg and Krishna Chaitanya Joshi \\ Neurology 2019;92;390 \\ DOI 10.1212/WNL.0000000000006951
}

This information is current as of February 18, 2019

Updated Information \&
Services

Subspecialty Collections

Permissions \& Licensing

Reprints including high resolution figures, can be found at: http://n.neurology.org/content/92/8/390.full

This article, along with others on similar topics, appears in the following collection(s):

All Cerebrovascular disease/Stroke

http://n.neurology.org/cgi/collection/all_cerebrovascular_disease_strok e

Critical care

http://n.neurology.org/cgi/collection/critical_care

Other Education

http://n.neurology.org/cgi/collection/other_education

Information about reproducing this article in parts (figures,tables) or in its entirety can be found online at:

http://www.neurology.org/about/about_the_journal\#permissions

Information about ordering reprints can be found online:

http://n.neurology.org/subscribers/advertise

Neurology ${ }^{\circledR}$ is the official journal of the American Academy of Neurology. Published continuously since 1951, it is now a weekly with 48 issues per year. Copyright @ 2019 American Academy of Neurology. All rights reserved. Print ISSN: 0028-3878. Online ISSN: 1526-632X.

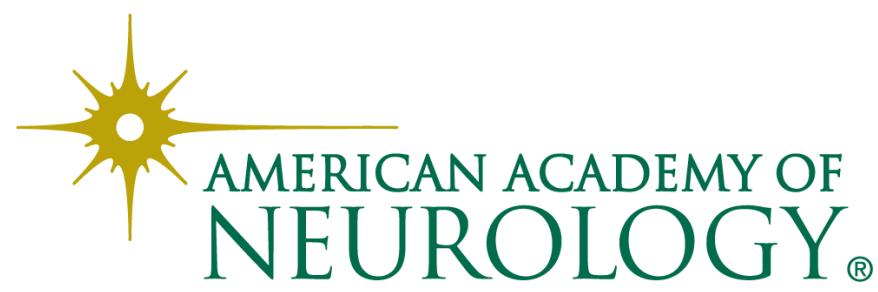

